\title{
Long term effect of liming and fertilization on ectomycorrhizal colonization and tree growth in old Scots pine (Pinus sylvestris L.) stands
}

\author{
Isabella Børja $\cdot$ Petter Nilsen
}

Received: 7 November 2007 / Accepted: 26 June 2008 / Published online: 29 July 2008

(C) The Author(s) 2008

\begin{abstract}
In this study, we surveyed the long term effects of liming and fertilizing in old Scots pine stands on the ectomycorrhiza (ECM) colonization, tree growth and needle nutrient concentration 35 years later. Four mature stands of Scots pine on low productive mineral soil were limed in 1959 and 1964 with total doses of limestone ranging from 3 to $15 \mathrm{Mg} \mathrm{ha}^{-1}$ and fertilized with nitrogen $(\mathrm{N})$ in 1970. Thirty-five years after the first liming treatment, all stands were analysed for tree growth and needle nutrient concentrations and two of the stands were also analysed for ECM colonization. ECM colonization increased significantly with liming from $61.5 \%$ in the control plots to $88 \%$ in the plot with the highest limestone dose. ECM colonization increased with increasing $\mathrm{pH}$ in the humus layer from $62 \%$ colonization at $\mathrm{pH}=3.5$ to $90 \%$ at $\mathrm{pH}=6.5$ and decreased with increasing amount of extractable phosphorus (P) in the humus. Liming did not affect the frequencies of different ECM morphotypes or dead short root tips,
\end{abstract}

Responsible Editor: Erik A. Hobbie.

I. Børja $(\bowtie)$

Norwegian Forest and Landscape Institute,

P.O. Box 115, 1431 Ås, Norway

e-mail: isabella.borja@skogoglandskap.no

P. Nilsen

The Research Council of Norway,

P.O. Box 2700 St. Hanshaugen,

0131 Oslo, Norway

e-mail: pn@forskningsradet.no the fine root biomass or necromass. ECM colonization was uncorrelated with needle nutrient concentrations or tree increment. Liming did not significantly affect tree growth. However, nutrient concentrations of currentyear needles were affected by prior liming. Ca concentrations in current-year needles increased from approximately $15 \mathrm{mg} \mathrm{g}^{-1}$ in control treatments to more than $30 \mathrm{mg} \mathrm{g}^{-1}$ in limed plots, whereas concentrations of $\mathrm{Mn}, \mathrm{Al}, \mathrm{Fe}$, and in two stands, $\mathrm{B}$, decreased due to liming. In conclusion, liming with doses up to $15 \mathrm{Mg}$ $\mathrm{ha}^{-1}$ was detectable in stands 35 years after treatment. The liming significantly increased the ECM colonization of Scots pine fine roots, increased the needle nutrient concentration of $\mathrm{Ca}$ and decreased the needle concentrations of $\mathrm{Mn}, \mathrm{Al}$, and $\mathrm{Fe}$.

Keywords Ectomycorrhiza $\cdot$ Liming $\cdot$ Fertilization Needle nutrient analysis $\cdot$ Scots pine $\cdot$ Tree increment
Abbreviations
ECM Ectomycorrhiza
EM Extramatrical mycelium

\section{Introduction}

At the end of the nineteenth century, liming and fertilization were used to increase forest production, but were abandoned in the 1950s due to lack of effect (Hüttl and Zöttl 1993; Nebe 1972; Nilsen 2001). In the 1980s, however, the use of liming was revived, 
this time as a possible countermeasure to increased anthropogenic acidification of forest soils. By adding high alkalinity fertilizers, termed liming, the $\mathrm{pH}$ and the acid neutralizing capacity of the soil increased (Derome et al. 1986; Hüttl and Zöttl 1993; Nilsen and Granheim 1998). In a similar fashion, the $\mathrm{N}$ fertilization experiments, which lower the soil $\mathrm{pH}$, were designed to provide insight in forest soil acidification processes (Kjønaas 2003; Nilsen 2001).

As liming and $\mathrm{N}$ fertilizing are known to change the soil chemical conditions, especially in the humus layer, where most of the absorbing fine roots are located, it could be expected that the roots and below ground organisms will be affected. The ectomycorrhiza (ECM), a vital symbiosis between the tree roots and fungi, is adapted to acidic soils in boreal forests (Read 1997). Thus large and long lasting increases in soil $\mathrm{pH}$ may have drastic effects on ECM species richness and number of mycorrhized fine roots.

Although the effects of $\mathrm{N}$ deposition are generally considered to be of relatively short duration ( $<10$ years), they have been shown to have a dramatic impact on the biological communities in the soil by reducing the fungal fruit-body yield (Lilleskov et al. 2002), biomass (Wallenstein et al. 2006), species richness (Kraigher et al. 1996), as well as altering the community structure (Allison et al. 2007; Treseder 2004; Wallenda and Kottke 1998 and references therein).

Conversely, the liming seems to have a long term effect, about 25-30 years, (Derome et al. 1986) and often results in higher fine root densities (Bakker et al. 2000; Erland and Söderström 1991; Kreutzer 1995) and higher below ground ECM species richness (Erland and Taylor 2002). However, some Finnish studies report on lower fine root biomass (Helmisaari and Hallbäcken 1999) and increased mortality of mycorrhizal root tips (Lehto 1994a, b) after liming.

Morphotyping of mycorrhizae revealed a general decrease in smooth mycorrhizae in favour of types with abundant extramatrical mycelium (EM), which may reflect the functional changes after liming (Bakker et al. 2000). The ECM fungi seem to differ in their ability to access and transfer $\mathrm{N}$ and $\mathrm{P}$ bound in the soil (Colpaert et al. 1996; Leake and Read 1997) and changes in ECM may therefore have effects on the nutritional status of the host plant.

Liming in Finland and Sweden reduced the tree growth by $5-20 \%$ in Scots pine stands on medium and low productive sites for a period up to 30 years (Andersson et al. 1996; Derome et al. 1986), whereas on more productive sites the growth was enhanced (Staaf et al. 1996).

As most of the studies on effect of liming use seedlings in relatively short term experiments, at present we still lack sufficient data for long term effects in forest ecosystems. The aim of our study was to survey the long term changes in ECM colonization, tree growth and needle nutrient concentration as related to the liming and $\mathrm{N}$ fertilization treatments applied in mature Scots pine stands 35 years earlier. Our first hypothesis was that the ECM may increase with the liming as higher soil $\mathrm{pH}$ has been shown to be more conducive to fine root and fungal growth. The second hypothesis was that as higher ECM colonization provides the potential for higher nutrient uptake, this will be reflected in the needle nutrient concentrations. Our third hypothesis was that, because of the documented decreased tree growth after liming, there will be no long term stimulating effect of liming on tree growth.

\section{Materials and methods}

\section{Site description}

Four Scots pine (Pinus sylvestris L.) stands, designated as 738, 740, 732 and 734, in central south-east Norway were chosen for the investigation. Two stands (738 and 740) were situated in Hedmark county $\left(60^{\circ}\right.$ $52^{\prime} \mathrm{N}, 12^{\circ} 0^{\prime} \mathrm{E}$ and $60^{\circ} 53^{\prime} \mathrm{N}, 11^{\circ} 57^{\prime} \mathrm{E}$ ), at $200 \mathrm{~m}$ asl. The site index was 9.5 according to the Norwegian site index classification system with a mean annual production of approximately $3 \mathrm{~m}^{3} \mathrm{ha}^{-1}$ year $^{-1}$. The vegetation type was a Vaccinio-Pinetum boreale (Kielland-Lund 1981) dominated by Vaccinium vitisidaea L., Calluna vulgaris (L.) Hull, Pleurozium schreberi (Willd.) Mitten. and Cladina spp. as the understorey. The stands were on a basal moraine dominated by sand and stone fractions. The mean thickness of the humus layer for the control plots was $4.8 \mathrm{~cm}$ and $4.2 \mathrm{~cm}$ within stands 738 and 740 , respectively. The two other stands (732 and 734) were situated in Buskerud county $\left(60^{\circ} 16^{\prime} \mathrm{N}, 9^{\circ} 58^{\prime} \mathrm{E}\right)$, at $200 \mathrm{~m}$ asl. on an old river terrace, also dominated by sand fractions and stones. The site index varied from 8.9 (stand 734) to 9.8 (stand 732) with a mean annual 
production of about 3-4 $\mathrm{m}^{3} \mathrm{ha}^{-1}$ year $^{-1}$. The vegetation type was a Vaccinio-Pinetum boreale with a higher dominance of Cladina spp. than on the two other stands. The thickness of the humus layer in the control plots averaged $4.0 \mathrm{~cm}$ and $4.2 \mathrm{~cm}$ in stands 732 and 738, respectively. The soils were classified as Typic Haplorthods (in 734 and 738) and Typic Udipsamments (in 732 and 740). Selected key data for the stands are presented in Tables 1 and 2.

\section{Treatments and experimental design}

Plots of $28 \times 28 \mathrm{~m}$ were treated with $3 \mathrm{Mg} \mathrm{ha}^{-1}$ of fine-grained limestone $\left(1,500 \mathrm{~kg} \mathrm{ha}^{-1} \mathrm{CaO}\right)$ in June and July 1959. The lime was of powder quality, common in commercial agriculture at that time and with a large proportion of fine material. There were four replicates for each treatment (Table 3). In 1964 the plots $(24 \times 24 \mathrm{~m})$ were treated with additional doses of limestone, varying from 0 to $12 \mathrm{Mg} \mathrm{ha}^{-1}$ (Table 3). As no plots within any one stand received the same limestone dose as any of the other plots, there were no replicates within the stand. Later, in 1970, all the limed plots were fertilised with $200 \mathrm{~kg} \mathrm{~N}$ $\mathrm{ha}^{-1}$ applied as granulated ammonium nitrate. An overview of the experimental design and treatments is given in Table 3.

\section{Sampling of ECM}

A grid system with a row distance of $3 \mathrm{~m}$ was used for the mycorrhiza sampling, and soil cores $(6 \mathrm{~cm}$ in diameter) were collected from the grid intersections in autumn 1994. The soil cores were taken from the humus layer in the stands 732 and 734, from eight and six plots (six cores per plot), respectively. The total number of soil cores sampled was thus 48 and 36 from stands 732 and 734, respectively. The thickness of the humus layer was measured after removing the moss and the litter layer. Each core was placed in a plastic bag and stored in the cold storage $\left(4^{\circ} \mathrm{C}\right)$ until analysis.

\section{Quantitative determination of ECM}

Each soil core was gently crumbled before examination. All fine roots (diameter $<2 \mathrm{~mm}$ ) were extracted and placed in a Petri dish filled with water. After gentle agitation, the water was changed until all roots were free of debris. Cleaned fine roots were separated into living and dead. The distinctions between dead and live fine roots were made on the basis of their appearance and tactile examination as described by Vogt and Persson (1991). Dead roots were shrivelled, dark in colour, non-turgid and disintegrated easily. Dead root fragments were oven-dried at $70^{\circ} \mathrm{C}$ for 3 days and weighed as fine root necromass. Living fine roots were evenly distributed on a soil sieve and the number of fine roots was counted with the aid of a dissecting microscope.

As it was not feasible to microscopically verify the presence of the Hartig net in each sample, the distinction between the non-mycorrhizal and ECM roots in this study was based on visual assessment. We considered roots to be non-mycorrhizal when they had root hairs, lacked visible fungal hyphae, or mantle and root tips were not swollen. In this study, no attempt was made to classify the ECM to species level. The most frequent morphotypes were distinguished based on their macroscopic characteristics and classified as Piloderma-like, Cenococcum-like (identified according to Agerer 1987-2002), morphotypes A: smooth mantle, light coloured; B: abundant, fluffy, rhizomorph-forming EM, white in colour; C:

Table 1 Stand parameters, mean annual precipitation and temperature (DNMI 2000) from the nearest climate stations, Nesbyen (stands 732, 734) and Trysil (stands 738, 740), measured at the control plots at the registration time point

\begin{tabular}{lllllllll}
\hline Stand & $\begin{array}{l}\text { Annual } \\
\text { precipitation } \\
(\mathrm{mm})\end{array}$ & $\begin{array}{l}\text { Mean annual } \\
\text { temperature } \\
\left({ }^{\circ} \mathrm{C}\right)\end{array}$ & $\begin{array}{l}\text { Total age } \\
(\text { years })\end{array}$ & $\begin{array}{l}\text { Site index } \\
\text { Ho at } \\
40 \text { years }\end{array}$ & $\begin{array}{l}\text { Number of } \\
\text { trees ha }{ }^{-1}\end{array}$ & $\begin{array}{l}\text { Standing } \\
\text { volume } \\
\left(\mathrm{m}^{3} \mathrm{ha}^{-1}\right)\end{array}$ & $\begin{array}{l}\text { Mean } \\
\text { height } \\
(\mathrm{HL} ; \mathrm{m})\end{array}$ & $\begin{array}{l}\text { Mean } \\
\text { diameter } \\
(\mathrm{cm})\end{array}$ \\
\hline 732 & 520 & 2.9 & 108 & 9.8 & 454 & 131 & 17.0 & 21.0 \\
734 & 520 & 2.9 & 143 & 8.9 & 339 & 139 & 18.0 & 24.4 \\
738 & 720 & 1.6 & 143 & 9.5 & 405 & 189 & 18.7 & 25.8 \\
740 & 720 & 1.6 & 128 & 9.3 & 518 & 195 & 18.8 & 23.1 \\
\hline
\end{tabular}


Table 2 Mean (std) values for $\mathrm{pH}$, total N (\% of dry matter), extractable P (mmol/kg), cation exchange capacity (mmol/kg) and base saturation in the humus layer in the control plots

\begin{tabular}{lllllll}
\hline Stand & Humus thickness, cm & $\mathrm{pH}$ in humus & Total N, \% & Extractable P & Cation exchange capacity & Base saturation, \% \\
\hline 732 & $3.0(0.4)$ & $3.63(0.13)$ & $1.18(0.27)$ & $2.75(1.24)$ & $256.5(52.4)$ & $28.1(7.6)$ \\
734 & $2.7(0.3)$ & $3.57(0.06)$ & $1.41(0.12)$ & $3.97(0.82)$ & $324.8(14.5)$ & $36.1(7.4)$ \\
738 & $3.2(0.4)$ & $3.55(0.10)$ & $1.07(0.15)$ & $6.65(0.81)$ & $327.3(35.2)$ & $37.4(2.1)$ \\
740 & $2.9(0.6)$ & $3.610 .11)$ & $1.13(0.15)$ & $5.94(0.17)$ & $322.1(29.1)$ & $38.4(1.4)$ \\
\hline
\end{tabular}

web-like EM, grey in colour and D: other mycorrhizae with EM. The dead fine roots still attached to the living primary roots were also counted as dead root tips.

After the ECM assessment the living roots were oven dried for 3 days at $70^{\circ} \mathrm{C}$, and dry weight determined separately as living fine root biomass.

In this paper, the ECM status was evaluated in terms of total number of ECM root tips and main ECM morphotypes, both in absolute numbers (number of tips per $\mathrm{m}^{2}$ humus) and as relative proportion. The term ECM colonization refers to the percentage of ECM root tips (total number of ECM root tips $\times$ $100 /$ total number of live root tips).

Tree increment measurements

Diameter and height were measured on all trees within a central plot of $16 \times 16 \mathrm{~m}$ in autumn 1992 . Increment cores were taken from each tree and year rings were measured in the laboratory with $0.01 \mathrm{~mm}$ accuracy. The basal area growth was calculated for a 50 -year period. The increment of each limed plot was compared to the control plot within the same replicate. The growth response for treated plots ( $\mathrm{ig}_{\text {res }}$ ) in a specific year after treatment was found by subtracting the increment that the plot would have had without treatment from the measured increment:

$\operatorname{ig}_{\text {res }}=\operatorname{ig}-\operatorname{igc}(\operatorname{ig} 10 / \operatorname{igc} 10)$,

where ig is the measured basal area increment for a treated plot in a specific year and igc is the basal area increment for the control plot in the same year, while ig10 and igc10 are the basal area increment in a 10 year period prior to liming for the treated and control plots, respectively. In stand 740 the increment was calculated up to 1985 due to a thinning in 1986 . The increment of thinned trees up to 1985 was estimated from their share of the total basal area, taken from tree measurements made in 1978.

The increment data were divided into three subsequent periods: period 1 (1959-1969) is the first period after the two liming treatments, period 2 (1970-1978) is the period after $\mathrm{N}$ fertilization and period 3 (1979-1992; 1985 in stand 740) is the period of potential long term effects.

Needle nutrient analyses

Needle samples were taken from five randomly chosen trees on each plot in September 1993. A south

Table 3 Experimental set up for the treatments with limestone and $\mathrm{N}$ doses on four Scots pine stands $(732,738,734$ and 740$)$ at different time points (years)

\begin{tabular}{|c|c|c|c|c|c|c|}
\hline \multirow{3}{*}{$\begin{array}{l}\text { Year } \\
\text { Treatment } \\
\text { No. of plots }\end{array}$} & \multirow{3}{*}{$\begin{array}{l}1959 \\
\text { Limestone }\left(\mathrm{Mg} \mathrm{ha}^{-1}\right) \\
\text { All stands }\end{array}$} & \multicolumn{4}{|l|}{1964} & \multirow{3}{*}{$\begin{array}{l}1970 \\
\mathrm{~N}\left(\mathrm{~kg} \mathrm{ha}^{-1}\right) \\
\text { All stands }\end{array}$} \\
\hline & & \multicolumn{4}{|c|}{ Limestone $\left(\mathrm{Mg} \mathrm{ha}^{-1}\right)$} & \\
\hline & & Stand 732 & Stand 738 & Stand 734 & Stand 740 & \\
\hline 4 & 0 & 0 & 0 & 0 & 0 & 0 \\
\hline 1 & 3 & 0 & 0 & 0 & 0 & 200 \\
\hline 1 & 3 & 5 & 5 & 6 & 6 & 200 \\
\hline 1 & 3 & 7.5 & 7.5 & 9 & 9 & 200 \\
\hline 1 & 3 & 10 & 10 & 12 & 12 & 200 \\
\hline
\end{tabular}


facing branch from the upper part of the tree crown was cut from each tree. Twigs from the current and last years were cut from these branches. Pooled samples from the five trees represented each plot for current $(\mathrm{C})$ and 1 year old $(\mathrm{C}+1)$ needles.

The needles were dried for 3 days at $70^{\circ} \mathrm{C}$, ground and analysed for chemical content according to Ogner et al. (1991). Total $\mathrm{N}$ was determined as ammonium after Kjeldahl digestion. Total elements in needles were determined by a simultaneous ICP-AES technique (Jarrel-Ash AtomComp 1100) in acid digested samples.

Soil sampling and chemical analyses

Each plot was divided into three sectors by a grid of $3 \mathrm{~m} \times 6 \mathrm{~m}$. Humus samples were taken at the 18 crossing points in 1991 and 1992 with a cylinder corer ( $6 \mathrm{~cm}$ diameter). The length of the humus cores was measured and they were then bulked into one sample per sector. Each bulk sample was dried at $25^{\circ}$ $\mathrm{C}$ for 3 days, sieved through a $2 \mathrm{~mm}$ mesh, ground and sent to chemical analysis.

The humus samples were analysed for dry matter content, total $\mathrm{C}$, total $\mathrm{N}, \mathrm{pH}_{\text {(water) }}$, cation exchange capacity and exchangeable acidity (Table 2). C and $\mathrm{N}$ were determined by an Elementar Vario EL with TCD detector on milled soil samples. Cation exchange capacity and acidity were measured after ammonium nitrate $(1 \mathrm{M})$ extraction using a Thermo Jarrel-Ash ICP-IRIS HR Duo instrument. pH (water added for one night) was measured with a radiometer $\mathrm{pH}$ meter PHM 220.
Statistical analyses

The original random experiment from 1959 with four replicates of limed and control plots was reorganised in 1964 because of additional liming (Table 3). We therefore analysed the ECM colonization according to a dose response concept: all control plots were averaged within each experiment (732 and 734) and simple regression analyses were performed in order to analyse lime dose effects.

Basal area increment responses $\left(\mathrm{ig}_{\mathrm{res}}\right)$ were also analysed by regression analysis. To correct for differences in pre-treatment increment we also performed a covariance analysis (unbalanced ANOVA) on the basal area increment (ig) in the four experiments. The covariate was the increment in the ten-year period prior to liming and the four experiments were organised together in a common analysis with the following treatments; A: control, B: $3 \mathrm{Mg}$ limestone, $\mathrm{C}: 8$ and $9 \mathrm{Mg}$ limestone, $\mathrm{D}: 10.5$ and $12 \mathrm{Mg}$ limestone and E: 13 and $15 \mathrm{Mg}$ limestone. The SAS programme package (SAS Version 6.11) was used in all computations (procedures GLM and REG).

\section{Results}

ECM colonization

The ECM colonization increased significantly $(p<$ 0.001 ) after liming, from $61.6 \%$ in the control plots to $88 \%$ in the plots with the highest limestone dose (Fig. 1). A similar significant tendency towards
Fig. 1 ECM colonization in relation to the limestone dose

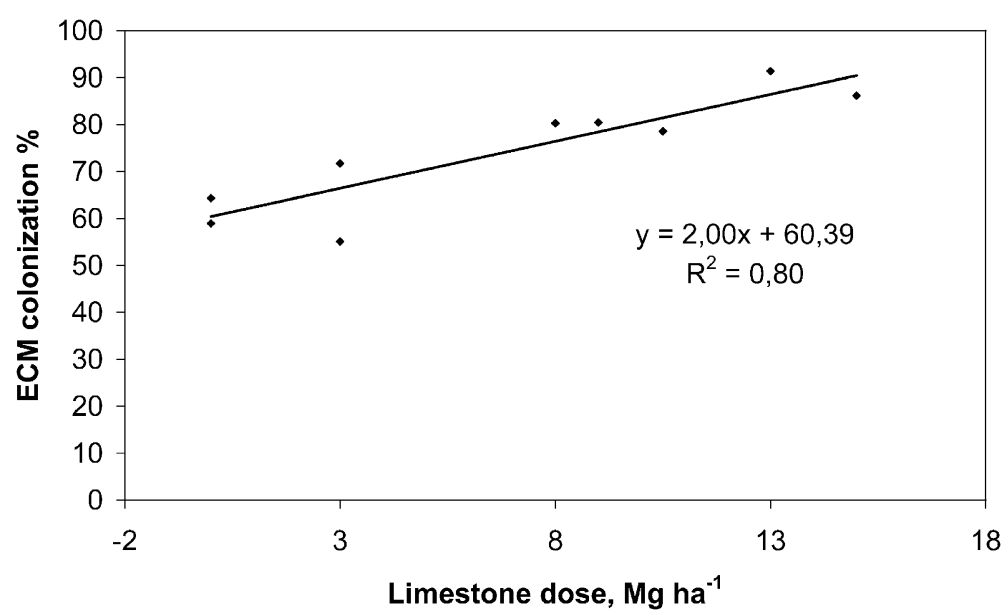


stimulated ECM colonization $(p=0.0018)$ was also detected with increasing soil $\mathrm{pH}$ as the ECM increased from $62 \%$ colonization at $\mathrm{pH}=3.5$ to $90 \%$ at $\mathrm{pH}=6.5 \mathrm{~m}$ (Tables 4 and 6). The ECM colonization decreased significantly $(p=0.032)$ with increasing amount of extractable phosphorus (P) in the humus (Fig. 2). The number of new or non-mycorrhizal root tips decreased significantly $(p<0.001)$ with increasing limestone dose (Fig. 3). No other significant effect of liming or $\mathrm{pH}$ in the soil was detected on any of the ECM morphotypes, the amount of dead root tips, fine root biomass and the necromass. Furthermore, there was no correlation between ECM colonization (or morphotype frequency) and needle nutrient concentrations or tree increment.

\section{Tree increment}

The results for the increment in the control treatments and in the treated plots varied among the three increment periods. The most obvious increment response was found in period 2, after the $\mathrm{N}$ application, with a total mean of $1.5 \mathrm{~m}^{2} \mathrm{ha}^{-1}$ in the 9 year period (Table 5). The limed plots did not differ significantly from the control plots in periods 1 and 3 . In stands 732 and 734 the highest lime dose induced retarded growth in the first period, while the opposite was the case in stands 738 and 740 (Table 5). In the third period the highest lime dose retarded the increment in stand 732 but increased the increment in the three other stands.

The basal area increment for the control plots in the periods ranged from 0.44 to $0.78 \mathrm{~m}^{2} \mathrm{ha}^{-1}$ year ${ }^{-1}$ (Table 5). The increment increase in periods 1 and 3 was at most $10.5 \%$ (stand 734 , dose $3 \mathrm{Mg} \mathrm{ha}^{-1}$ ). Regression analyses showed no correlation between increment increase and the lime dose in any of the periods. The basal area growth increase equalled on average $-1.3 \%, 71.8 \%$ and $6.5 \%$ in the first, second and third periods, respectively.

The analysis of covariance, with the increment in the 10 -year period prior to liming as the covariate, showed no significant effects of the different lime doses on the increment. The treatments were then pooled into four classes of lime doses. In the second period, after the $\mathrm{N}$ application, all classes showed a significantly higher increment than the control. However, no differences in effect among the different lime doses could be found.

Needle nutrient concentrations

Apart from N, no nutrients had under-optimal concentration levels for growth (Table 6). Overall

Table 4 Mean values (number of tips, 1,000 tips per square meter) and proportions (\%) for ECM and non-mycorrhizal root tips, fine root biomass and necromass $\left(<2 \mathrm{~mm}, \mathrm{gm}^{-2}\right)$ on two Scots pine stands treated with different lime doses $\left(0-15 \mathrm{Mg} \mathrm{ha}^{-1}\right)$

\begin{tabular}{|c|c|c|c|c|c|c|c|c|c|}
\hline \multirow[b]{2}{*}{ Lime dose $\left(\mathrm{Mg} \mathrm{ha}^{-1}\right)$} & \multicolumn{5}{|c|}{ Stand 732} & \multicolumn{4}{|c|}{ Stand 734} \\
\hline & 0 & 3 & 8 & 10.5 & 13 & 0 & 3 & 9 & 15 \\
\hline No. of plots & 4 & 1 & 1 & 1 & 1 & 3 & 1 & 1 & 1 \\
\hline Non-mycorrhizal tips $\left(1,000 \mathrm{tips} / \mathrm{m}^{2}\right) *$ & 157 & 111 & 96 & 98 & 45 & 198 & 209 & 81 & 16 \\
\hline ECM colonization $(\%)^{* *}$ & 64.3 & 71.7 & 80.2 & 78.5 & 91.3 & 58.9 & 55.1 & 80.4 & 86.1 \\
\hline Dead root tips $\left(1,000 \mathrm{tips} / \mathrm{m}^{2}\right)$ & 18 & 9 & 25 & 16 & 19 & 45 & 38 & 26 & 31 \\
\hline Fine root biomass $\left(\mathrm{g} / \mathrm{m}^{2}\right)$ & 73.3 & 69.0 & 75.5 & 158.1 & 78.4 & 62.9 & 67.2 & 59.6 & 21.8 \\
\hline Fine root necromass $\left(\mathrm{g} / \mathrm{m}^{2}\right)$ & 0.9 & 0 & 7.1 & 0 & 0 & 9.4 & 12.4 & 0 & 21.8 \\
\hline \multicolumn{10}{|l|}{ ECM morphotypes $\left(1,000\right.$ tips $\left./ \mathrm{m}^{2}\right)$} \\
\hline Cenococcum-like & 212 & 185 & 258 & 252 & 376 & 223 & 143 & 217 & 864 \\
\hline Piloderma-like & 1.8 & 0.9 & 1.2 & 0.3 & 0.6 & 0.1 & 0 & 0 & 0 \\
\hline Morphotype A & 69 & 52 & 56 & 80 & 39 & 56 & 42 & 49 & 11 \\
\hline Morphotype B & 15 & 37 & 17 & 16 & 51 & 5 & 36 & 25 & 2 \\
\hline Morphotype C & 1.9 & 3.9 & 4.0 & 10.8 & 5.7 & 3.7 & 0.6 & 6.7 & 0.2 \\
\hline Morphotype D & 3.2 & 2.4 & 54.3 & 0.1 & 3.7 & 15.4 & 34.9 & 34.6 & 1.8 \\
\hline Total ECM tips & 303 & 281 & 391 & 359 & 476 & 303 & 257 & 333 & 879 \\
\hline
\end{tabular}

Morphotypes $A$ Smooth mantle, light coloured; $B$ abundant, fluffy, rhizomorph-forming EM, white in colour; $C$ web-like EM, grey in colour, $D$ other mycorrhizae with EM

${ }^{*} p<0.001$, significant effect of lime dose, $R^{2}=0.62, \mathrm{CV} 11.5 \% ; * * p<0.001$; significant effect of lime dose, $R^{2}=0.65, \mathrm{CV} 29.4 \%$ 
Fig. 2 ECM colonization in relation to the content of extractable phosphorus $(\mathrm{P})$

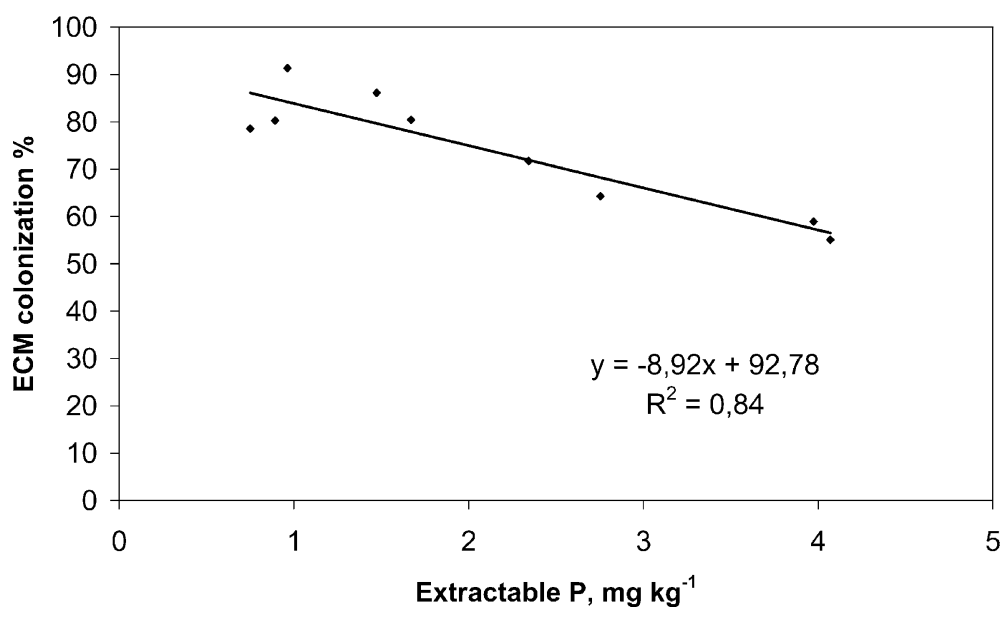

regression analyses of nutrient concentrations in the four stands showed a significant positive correlation between $\mathrm{Ca}$ and limestone dose, for both $\mathrm{C}$ and $\mathrm{C}+1$ needles (Table 6, only $\mathrm{C}$ needles shown). For $\mathrm{Al}$ and $\mathrm{Mn}$ a significant negative correlation with dose was found for both needle ages (Table 6). Fe showed a weak, but significant, negative correlation with limestone dose for the $\mathrm{C}+1$ needles (data not shown). The $\mathrm{B}$ concentration was also negatively affected by the lime treatment in stands 732 and 734 and reached levels of $5 \mu \mathrm{g} \mathrm{g}^{-1}$, whereas an opposite trend could be seen in the two other stands.

A second degree linear regression between $\mathrm{Ca}$ concentration and limestone dose showed a rather stable $\mathrm{Ca}$ concentration from 8 to $15 \mathrm{Mg}$ limestone dose, with a curve optimum at approximately $12 \mathrm{Mg}$. For $\mathrm{Mn}$ and $\mathrm{Al}$ concentrations the decrease was nearly linear in the 8 to $15 \mathrm{Mg}$ interval.

\section{Discussion}

Because of the additional $\mathrm{N}$ fertilization in 1970, with an equal dose of $\mathrm{N}$ applied to all limed plots (Table 3), we had no possibility to compare either the liming or fertilizing effects separately, but only in combination. However, numerous studies reviewed by Wallenda and Kottke (1998) have revealed that N fertilization causes at most short term changes in mycorrhizal colonization and species diversity, as estimated from investigations of mycorrhizal root tips that were similar to ours. For tree increment the effects of $\mathrm{N}$ fertilization are reported to last for 6-8 years after application (Nilsen 2001).

As our results agree with the typical liming effects described in previous findings, such as increasing quantity of mycorrhizal roots (Bakker et al. 2000; Nowotny et al. 1998), it is probable that the $\mathrm{N}$
Fig. 3 Non-mycorrhizal root tips $\left(1,000\right.$ tips per $\mathrm{m}^{2}$ humus layer) in relation to limestone dose

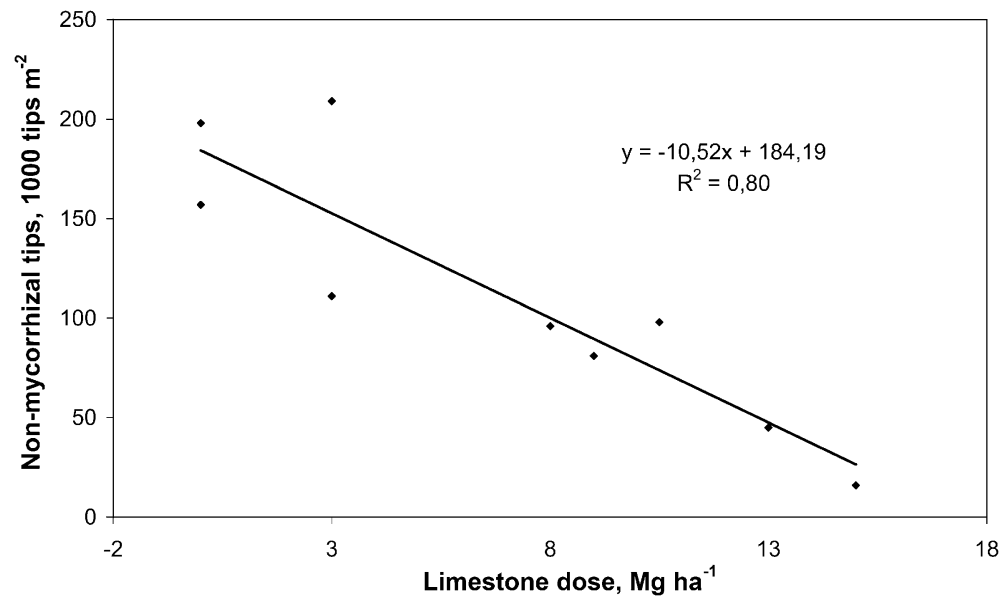


Table 5 The basal area increment $\left(\mathrm{m}^{2} \mathrm{ha}^{-1}\right)$ for the control plots (dose 0$)$ in the three periods after the first liming in the four Scots pine stands and the increment increase $\left(\mathrm{m}^{2} \mathrm{ha}^{-1} \mathrm{year}^{-1}\right)$ in the limed plots compared to the controls

\begin{tabular}{|c|c|c|c|c|c|}
\hline Stands & Dose & Period 1 & Period 2 & Period 3 & All periods \\
\hline \multirow[t]{5}{*}{732} & 0 & 8.47 & 8.89 & 10.77 & 28.13 \\
\hline & 3 & -0.51 & 1.10 & -0.37 & 0.21 \\
\hline & 8 & -0.37 & 0.18 & 0.13 & -0.06 \\
\hline & 10.5 & 0.25 & 0.98 & -0.60 & 0.63 \\
\hline & 13 & -0.13 & 0.48 & -0.22 & 0.14 \\
\hline \multirow{4}{*}{734} & 0 & 4.85 & 5.22 & 7.03 & 17.10 \\
\hline & 3 & 0.51 & 2.26 & -0.03 & 2.74 \\
\hline & 9 & 0.00 & 0.61 & -0.24 & 0.38 \\
\hline & 15 & -0.42 & 0.63 & 0.49 & 0.69 \\
\hline \multirow[t]{5}{*}{738} & 0 & 6.23 & 7.64 & 10.94 & 24.81 \\
\hline & 3 & 0.04 & 2.05 & 0.35 & 2.44 \\
\hline & 8 & 0.06 & 1.80 & 1.02 & 2.87 \\
\hline & 10.5 & 0.05 & 2.36 & 1.37 & 3.78 \\
\hline & 13 & 0.07 & 1.41 & 0.17 & 1.66 \\
\hline \multirow[t]{5}{*}{740} & 0 & 7.58 & 10.73 & 7.09 & 25.40 \\
\hline & 3 & -0.66 & 0.46 & -0.74 & -0.93 \\
\hline & 9 & 0.70 & 3.33 & 0.01 & 4.03 \\
\hline & 12 & -0.70 & 1.96 & 0.24 & 1.50 \\
\hline & 15 & 0.68 & 3.26 & 0.50 & 4.43 \\
\hline Total mean & & -0.03 & 1.52 & 0.14 & \\
\hline
\end{tabular}

Period 1 1959-1969, period 2 1970-1978, period 3 1979-1992 (1985 for stand 740)

Table 6 Concentrations of macro- $\left(\mathrm{mg} \mathrm{g}^{-1}\right)$ and micro- $(\mathrm{ppm})$ nutrients and $\mathrm{Al}(\mathrm{ppm})$ in the current year needles in the Scots pine stands treated with varying limestone dose

\begin{tabular}{|c|c|c|c|c|c|c|c|c|c|c|c|c|c|c|}
\hline Stand & Limestone, $\mathrm{Mg} \mathrm{ha}^{-1}$ & $\mathrm{pH}$ in humus & $\begin{array}{l}\mathrm{N} \\
\mathrm{mg} \mathrm{g}^{-1}\end{array}$ & $\mathrm{P}$ & K & $\mathrm{Mg}$ & $\mathrm{Ca}$ & $\mathrm{S}$ & $\begin{array}{l}\mathrm{Mn} \\
\mathrm{ppm}\end{array}$ & $\mathrm{Cu}$ & $\mathrm{B}$ & $\mathrm{Zn}$ & $\mathrm{Fe}$ & $\mathrm{Al}$ \\
\hline \multirow[t]{5}{*}{732} & 0 & 3.63 & 12.1 & 1.5 & 4.9 & 0.9 & 1.7 & 0.8 & 315 & 2.9 & 11.8 & 38.3 & 31.1 & 234 \\
\hline & 3 & 3.88 & 11.8 & 1.6 & 5.2 & 1.0 & 2.0 & 0.8 & 269 & 3.2 & 10.7 & 40.4 & 31.7 & 210 \\
\hline & 8 & 4.82 & 13.4 & 1.8 & 6.3 & 1.1 & 3.3 & 0.9 & 347 & 2.8 & 11.0 & 45.9 & 33.9 & 208 \\
\hline & 10.5 & 5.31 & 12.7 & 1.6 & 4.9 & 1.1 & 4.1 & 0.8 & 225 & 2.8 & 8.6 & 38.3 & 27.4 & 153 \\
\hline & 13 & 5.43 & 11.5 & 1.4 & 4.5 & 0.9 & 3.4 & 0.7 & 213 & 2.4 & 5.1 & 31.8 & 24.0 & 122 \\
\hline \multirow[t]{4}{*}{734} & 0 & 3.57 & 11.2 & 1.4 & 5.3 & 0.9 & 1.7 & 0.7 & 339 & 3.1 & 9.4 & 36.0 & 29.0 & 196 \\
\hline & 3 & 4.06 & 11.9 & 1.5 & 4.8 & 1.1 & 2.5 & 0.7 & 378 & 2.9 & 7.0 & 38.5 & 27.0 & 246 \\
\hline & 9 & 4.72 & 11.6 & 1.4 & 5.5 & 0.9 & 3.5 & 0.8 & 276 & 2.9 & 6.7 & 40.0 & 26.5 & 226 \\
\hline & 15 & 5.63 & 11.5 & 1.4 & 5.2 & 0.8 & 3.6 & 0.8 & 142 & 3.0 & 5.1 & 32.5 & 26.1 & 125 \\
\hline \multirow[t]{5}{*}{738} & 0 & 3.55 & 11.5 & 1.4 & 5.5 & 0.9 & 1.4 & 0.7 & 513 & 2.6 & 7.7 & 29.6 & 29.6 & 162 \\
\hline & 3 & 3.62 & 11.2 & 1.4 & 5.7 & 0.9 & 2.2 & 0.8 & 544 & 2.6 & 9.6 & 32.8 & 26.1 & 208 \\
\hline & 8 & 4.32 & 11.1 & 1.4 & 5.5 & 0.9 & 2.5 & 0.7 & 371 & 2.6 & 9.2 & 26.9 & 28.4 & 154 \\
\hline & 10.5 & 4.86 & 11.2 & 1.4 & 5.8 & 0.9 & 2.6 & 0.7 & 328 & 2.6 & 10.4 & 28.8 & 25.7 & 135 \\
\hline & 13 & 4.40 & 14.6 & 1.6 & 5.9 & 0.7 & 2.6 & 0.9 & 269 & 2.5 & 9.0 & 29.6 & 25.0 & 104 \\
\hline \multirow[t]{5}{*}{740} & 0 & 3.61 & 12.5 & 1.6 & 5.1 & 0.8 & 1.1 & 0.8 & 449 & 2.0 & 3.2 & 28.4 & 27.1 & 130 \\
\hline & 3 & 3.64 & 11.3 & 1.5 & 5.5 & 1.0 & 2.4 & 0.8 & 495 & 3.1 & 6.3 & 32.5 & 89.2 & 144 \\
\hline & 9 & 6.06 & 11.9 & 1.5 & 5.1 & 0.9 & 2.5 & 0.8 & 238 & 2.6 & 4.9 & 31.1 & 28.0 & 111 \\
\hline & 12 & 6.02 & 12.7 & 1.6 & 5.6 & 0.8 & 2.1 & 0.8 & 233 & 2.5 & 3.8 & 26.7 & 25.1 & 105 \\
\hline & 15 & 6.20 & 11.0 & 1.5 & 5.3 & 1.0 & 2.7 & 0.8 & 273 & 2.2 & 10.2 & 26.9 & 29.9 & 119 \\
\hline
\end{tabular}


fertilization effect was not detectable in our current study two decades later. Hence, we consider the results described here as mostly due to liming, although other synergistic effects of liming and $\mathrm{N}$ fertilization cannot be excluded.

\section{ECM colonization}

The pine roots in our study showed a significant stimulating effect of liming on ECM colonization even 35 years after the first liming amendment of the forest soil. Similar long term effects have been reported previously by Bakker et al. (2000) on oak roots, where they showed an increase in mycorrhizal colonization after moderate liming doses 27 years later. This increase was explained mainly as the increased total root length after liming. In our case the total number of live root tips remained unchanged throughout the $\mathrm{pH}$ range but the ECM colonization seemed to increase on behalf of the non-mycorrhized root tips. The significant increase in ECM colonization was not related to any other of the parameters that we studied than liming dose and soil $\mathrm{pH}$.

Several studies indicate a shift in mycorrhizal types rather than a total increase in mycorrhizal colonization as a result of liming (Erland and Taylor 2002; Lehto 1984,1994a; Wallander et al. 1997). Some authors have reported that liming in general decreases the relative proportion of smooth ectomycorrhizae in favour of the hairy types (Bakker et al. 2000; Lehto 1994a) while others have reported different abundances of mycorrhizal types (Erland and Söderström 1990). In contrast to these studies, we did not find any significant shift in ECM morphotypes due to liming. However, this may be due to our simplified methodological approach, where our rough morphotyping may not have been precise enough to disclose the differences between them.

Liming decreases the soil acidity and the accompanying $\mathrm{pH}$ change in soil is known to affect the mycorrhizal colonization (Erland and Söderström 1990; Lehto 1994a, b). Nowotny et al. (1998) reported a two-fold increase of the annual mean quantity of Norway spruce mycorrhizal roots in the humus 6 years after liming and attributed this effect to the increase in soil $\mathrm{pH}$. This was confirmed in our study, where the ECM colonization increased with the increasing $\mathrm{pH}$ in the humus layer (Tables 4 and 6) in the same manner as with increasing lime dose (Fig. 1). Our results are in agreement with studies referring to mycorrhizal colonization being significantly related to the $\mathrm{pH}$ in either long term field studies (Bakker et al. 2000) or short term laboratory studies (Erland and Söderström 1990).

In addition to a $\mathrm{pH}$ shift, liming may also alter the availability of certain elements in the soil, such as $\mathrm{N}$ and P (Haynes 1982), which are known to affect mycorrhizal colonization (Newton and Pigott 1991). In our study the ECM colonization decreased with the increasing amount of extractable $\mathrm{P}$ in the humus (Fig. 3). The mycorrhizal association usually increases the plants uptake of $\mathrm{P}$, where the mycorrhizal fungi make the $\mathrm{P}$ available by various mechanisms (Bolan 1991). The decrease in ECM colonization in our case occurred simultaneously with an increase of $\mathrm{P}$. Whether the decrease in ECM colonization in environments with increased $P$ reflects a diminished demand of plants for P-uptake provided by fungi remains to be determined. Although Wallander et al. (1997) found that liming caused a shift in the ectomycorrhizal community of Scots pine depending on the nutritional requirements of the fungi (favouring fungi which used inorganic $\mathrm{N}$ rather than organic), the increase of $\mathrm{P}$ availability in our case did not affect the ECM morphotypes.

Finally, it remains unclear whether the increase in ECM is a primary result of the nutrient demand of the plant or a reflection of the adaptation of ECM fungi to the chemical composition of the soil. Lehto (1994a) pointed out that changes in mycorrhizal colonization appear soon after liming and may be present up to 12 years after liming. We show that the effect may persist up to 35 years.

Liming has also been shown to increase the fine root growth, especially in the humus layer (Bakker et al. 2000; Kreutzer 1995; Nowotny et al. 1998), an effect related to improved soil fertility. In Finland, on nutrient poor, relatively unpolluted forest sites, Helmisaari and Hallbäcken (1999) found a decrease in fine root biomass in Norway spruce in response to liming, while increased root growth was found in a heavily polluted pine stand closest to a copper-nickel smelter (Helmisaari et al. 1999), indicating that the fine root biomass is dependent on edaphic conditions. In our study, in pine stands growing on low productive mineral soil (Tables 1 and 2), we found no effect of liming on the fine root biomass. 
Tree growth

The tree increment was affected to only a small degree by the liming treatments. The lack of replicates made it difficult to discern an overall trend. The small negative effect of $-1.3 \%$ in the first period after liming, the N-stimulated increment in the second period and the slight positive effect in the third period are in agreement with comparable Swedish and Finnish results (Andersson et al. 1996; Derome et al. 1986).

\section{Needle nutrient concentration}

The elevated $\mathrm{Ca}$ concentrations in needles in the limed plots that we present here have been documented in other studies as well. Nihlgård et al. (1996) summarised Swedish experiments showing a longterm increase in $\mathrm{Ca}$ concentration in needles due to liming. Similar results have been reported from Germany in spruce and fir (Aldinger 1987). However, Derome et al. (1986) found no significant Ca increase in pine forest needles 20 years after liming. They did however find an increase in $\mathrm{Mg}$ concentration, presumably due to the fact that a dolomitic limestone was used (containing $\mathrm{Mg}$ instead of $\mathrm{Ca}$ ).

The decrease in Mn concentration is also in good agreement with earlier findings (Nihlgård et al. 1996), where $\mathrm{Mn}$ concentrations decreased from 600 to $700 \mu \mathrm{g} \mathrm{g}^{-1}$ in control plots to the range of $300-$ $500 \mu \mathrm{g} \mathrm{g}^{-1}$ in limed plots (Table 6). However, no effect on Mn concentration was found in Finnish studies (Derome et al. 1986), although this may be because only a $3 \mathrm{Mg}$ limestone dose was applied. A decrease in $\mathrm{Al}$ concentrations was also found with increasing limestone dose in the present investigation. However, this effect was expected because as the liming increases the soil $\mathrm{pH}$, it causes the $\mathrm{Al}$ to precipitate by forming aluminium hydroxides, thus decreasing the Al solubility in the soil. A similar process is known for $\mathrm{Mn}$, where the solubility of $\mathrm{Mn}$ decreases with increasing soil $\mathrm{pH}$, forming $\mathrm{MnO}_{2}$ (Nihlgård et al. 1996). Thus, the decreased concentrations of $\mathrm{Al}$ and $\mathrm{Mn}$ in the needles found in our study may be due to the precipitating (immobilizing) effect of liming on these two elements.

Although B has also been found to be less available to pine trees after liming (Aronson 1983), this did not seem to be the case in two stands ( 738 and 740) in our study. Both these stands had initially rather low $\mathrm{B}$ needle concentrations compared to stands 732 and 734 (Table 6), which may have contributed to the increase of B concentrations in needles after liming. Also, the stand 740 was topographically the most variable, which may have additionally affected the increase of $\mathrm{B}$ concentrations in the needles here.

An overall evaluation of the nutrient conditions of the stands is that large doses of lime will decrease the $\mathrm{Mn}, \mathrm{Al}$ and $\mathrm{Fe}$ availability and increase the $\mathrm{Ca}$ availability. However, none of these effects appeared to have any significance for the tree growth and productivity. The only element that seemed to be deficient was $\mathrm{N}$; all other elements were above the deficiency levels (Brække 1996).

In conclusion, in agreement with our first hypothesis, we found an increased ECM colonization as an effect of liming, although no effects were detected in the richness of the ECM morphotypes. In support of our second hypothesis, we also found changes in the nutrient content of the needles (increase of $\mathrm{Ca}$ and decrease of $\mathrm{Mn}, \mathrm{Al}$ and $\mathrm{Fe}$ ) as an effect of liming. In agreement with our third hypothesis we did not detect any significant effect of liming on the tree growth.

Acknowledgements We wish to thank Frank Newell Kidder, Roald Brean and Elin Gjems Børresen for their excellent technical help. We are grateful to the Ministry of Agriculture and Food, the Ministry of the Environment and the Norwegian Forest and Landscape Institute for their financial support. Finally, we thank two anonymous reviewers for their constructive comments.

Open Access This article is distributed under the terms of the Creative Commons Attribution Noncommercial License which permits any noncommercial use, distribution, and reproduction in any medium, provided the original author(s) and source are credited.

\section{References}

Agerer R (1987-2002) Colour atlas of Ectomycorrhizae. EinhornVerlag Eduard Dietenberger GmbH, Schwäbisch Gmünd

Aldinger E (1987) Elementgehalte im Boden in Nadeln verschiedenen stark geschädigter Fichten-Tannen-Bestände auf Praxiskalkungsflächen im Bundsandstein-Schwarzwald. Freibg Bodenkdl Abh 19:266

Allison SD, Hanson CA, Treseder KK (2007) Nitrogen fertilization reduces diversity and alters community structure of active fungi in boreal ecosystems. Soil Biol Biochem 39:1878-1887 
Andersson R, Hallbäcken L, Popovic B (1996) Kalkning och trädtilväkst. In: Skogmarkskalkning. Eds. H Staaf, T Persson and U Bertills. Naturvårdsverkets förlag, Stockholm, pp 122-133

Aronson A (1983) Growth disturbances caused by boron deficiency in some fertilized pine and spruce stands on mineral soils. Commu Inst For Fenn 116:116-122

Bakker MR, Garbaye J, Nys C (2000) Effect of liming on the ectomycorrhizal status of oak. For Ecol Man 126:121-131

Bolan NS (1991) A critical review on the role of mycorrhizal fungi in the uptake of phosphorus by plants. Plant Soil 134:189-207

Brække FH (1996) Needle analyses and graphic vector analyses of Norway spruce and Scots pine stands. Trees 11:23-33

Colpaert JV, Van Leare A, Van Assche JA (1996) Carbon and nitrogen allocation in ectomycorrhizal and non-mycorrhizal Pinus sylvestris L. seedlings.. Tree Physiol 16:787-789

Derome J, Kukkola M, Mälkönen E (1986) Forest liming on mineral soils. Results of Finnish experiments. In: National Swedish Environment Board Report 3084. pp 1-107, Solna Sweden

Erland S, Söderström B (1990) Effects of liming on ectomycorrhizal fungi infecting Pinus sylvestris L. 1. Mycorrhizal infection in limed humus in the laboratory and isolation of fungi from mycorrhizal roots. New Phytol 115:675-682

Erland S, Söderström B (1991) Effects of lime and ash treatments on ecto-mycorrhizal infection of Pinus sylvestris L. seedlings planted in pine forest. Scand J For Res 6:519526

Erland S, Taylor AFS (2002) Diversity of ecto-mycorrhizal fungal communities in relation to the abiotic environment. In: van der Heijden MGA, Sanders IR (eds) Mycorrhizal ecology. Springer, Berlin, pp 163-200

Haynes RJ (1982) Effects of liming on phosphate availability in acid soils. Plant Soil 68:289-308

Helmisaari H-S, Hallbäcken L (1999) Fine-root biomass and necromass in limed and fertilized Norway spruce (Picea abies (L.) Karst.) stands. For Ecol Man 119:99-110

Helmisaari H-S, Makkonen K, Olsson M et al (1999) Fine-root growth, mortality and heavy metal concentrations in limed and fertilized Pinus silvestris (L.) stands in the vicinity of a Cu-Ni smelter in SW Finland. Plant Soil 209:193-200

Hüttl RF, Zöttl HW (1993) Liming as a mitigating tool to forest decline. For Ecol Man 61:325-338

Kielland-Lund J (1981) Die Waldgesellschaften SO-Norwegens. Phytocoenologia 9:53-250

Kjønaas OJ (2003) Nitrogen dynamics in a coniferous forest: effects of $\mathrm{N}$ input on cycling and $\mathrm{N}$ transformation rates. Dr Aric thesis. Agricultural University of Norway, Ås Norway

Kraigher H, Batic F, Agerer R (1996) Types of ecto-mycorrhizae and mycobioindication of forest site pollution. Phyton 36:115-120

Kreutzer K (1995) Effects of forest liming on soil processes. Plant Soil 168-169:447-470

Leake JR, Read DJ (1997) Mycorrhizal fungi in terrestrial ecosystems. In: Wicklow D, Söderström B (eds) The
Mycota IV experimental and microbial relationships. Springer, Berlin, pp 281-301

Lehto T (1984) The effect of liming on the mycorrhizae of Scots pine. Folia For 609:1-20

Lehto T (1994a) Effects of liming and boron fertilization on mycorrhizas of Picea abies. Plant Soil 163:65-68

Lehto T (1994b) Effects of soil $\mathrm{pH}$ and calcium on mycorrhizas of Picea abies. Plant Soil 163:69-75

Lilleskov EA, Fahey TJ, Horton TR et al (2002) Belowground ectomycorrhizal fungal community change over a nitrogen deposition gradient in Alaska. Ecology 83:104-115

Nebe W (1972) Langfreistige Wirkungen reiner Kalkungen auf das Baumwachstum. Beitr Forstwirtsch 1:17-21

Newton AC, Pigott CD (1991) Mineral nutrition and mycorrhizal infection of seedling oak and birch. II. The effects of fertilizers on growth, nutrient uptake and ectomycorrhizal infection. New Phytol 117:45-52

Nihlgård B, Popovic B, Fransman B et al (1996) Kalkningseffekter på trädens näringstilllstånd. In: Skogmarkskalkning. Eds. H Staaf, T Persson and U Bertills. pp 111-121. Naturvårdsverkets förlag, Stockholm

Nilsen P (2001) Fertilization experiments on forest mineral soils: a review of the Norwegian results. Scand J For Res 16:541-554

Nilsen P, Granheim O (1998) Langsiktige virkninger av kalking på trær og vegetasjon. In: FoU-programmet "Miljøtiltak $\mathrm{i}$ skog” Rapp Skogforsk. Ed. P Nilsen. pp 17-21. Norsk Institutt for Skogforskning, Ås Norway

Nowotny I, Dähne J, Klingenhöfer D et al (1998) Effect of artificial soil acidification and liming on growth and nutrient status of mycorrhizal roots of Norway spruce (Picea abies L. Karst.). Plant Soil 199:29-40

Ogner G, Opem M, Remedios G et al (1991) The chemical analysis program at the Norwegian Forest Research Institute, 1991. Norwegian Forest Research Institute, Ås Norway, pp 1-21

Read DJ (1997) Mycorrhizas in ecosystems. Experientia 47:376-391

Staaf H, Persson T, Bertills U (1996) Skogmarkskalking. Resultat och slutsatser från Naturvårdsverkets forsøksverksamhet. In: Skogmarkskalkning. Eds. H Staaf, T Persson and U Bertills. p. 290. Naturvårdsverkets förlag, Stockholm

Treseder KK (2004) A meta-analysis of mycorrhizal responses to nitrogen, phosphorus and atmospheric $\mathrm{CO}_{2}$ in field studies. New Phytol 164:347-355

Vogt KA, Persson H (1991) Measuring growth and development of roots. In: Lassoie JP, Hinckley TM (eds) Techniques and approaches in forest tree ecophysiology. CRC, Boca Raton

Wallander H, Arnebrant K, Östrand F et al (1997) Uptake of ${ }^{15} \mathrm{~N}$-labelled alanine, ammonium and nitrate in Pinus sylvestris L. ectomycorrhiza growing in forest soil treated with nitrogen, sulphur or lime. Plant Soil 195:329-338

Wallenda T, Kottke I (1998) Nitrogen deposition and ectomycorrhizas. New Phytol 139:169-187

Wallenstein MD, McNulty S, Fernandez IJ et al (2006) Nitrogen fertilization decreases forest soil fungal and bacterial biomass in three long-term experiments. For Ecol Man 222:459-468 